\title{
Reduced Sensitivity to Azoxystrobin of Monilinia fructicola Isolates From Brazilian Stone Fruits is Not Associated With Previously Described Mutations in the Cytochrome $b$ Gene
}

\begin{abstract}
Wagner V. Pereira, Departamento de Fitotecnia e Fitossanitarismo, Universidade Federal do Paraná, R. Funcionários, 1540, 80.035-050, Curitiba, PR, Brazil; Isabela V. Primiano, Departamento de Fitopatologia e Nematologia, Escola Superior de Agricultura "Luiz de Queiroz", Universidade de São Paulo, 13418-900, Piracicaba, SP, Brazil; Rafael G. F. Morales, Departamento de Fitotecnia e Fitossanitarismo, Universidade Federal do Paraná, R. Funcionários, 1540, 80.035-050, Curitiba, PR, Brazil; Natalia A. Peres, University of Florida, Gulf Coast Research and Education Center, Wimauma 33598; Lilian Amorim, Departamento de Fitopatologia e Nematologia, Escola Superior de Agricultura "Luiz de Queiroz", Universidade de São Paulo, 13418-900, Piracicaba, SP, Brazil; and Louise L. May De Mio, Departamento de Fitotecnia e Fitossanitarismo, Universidade Federal do Paraná, R. Funcionários, 1540, 80.035-050, Curitiba, PR, Brazil
\end{abstract}

\begin{abstract}
Quinone-outside inhibitor (QoI) fungicides are effective tools for preharvest control of brown rot of stone fruit. These fungicides have a very specific site of action so the risk of resistance selection is high. The sensitivity of Monilinia fructicola (G. Winter) Honey isolates to azoxystrobin (QoI) was investigated in 143 isolates collected between 2002 and 2011 from four Brazilian states in orchards with different frequencies of fungicide use (0 to 6 fungicides sprays/season). Sensitivity of the isolates to azoxystrobin was determined in vitro, by inhibition of mycelial growth and spore germination on fungicideamended media or ex vivo by pathogen inoculation in untreated or treated fruit with azoxystrobin. Potential mutations in codons 143 ,

137, and 129 of the cytochrome $\mathrm{b}(C y t b)$ gene and the occurrence of an intron immediately after codon 143 were analyzed in a subpopulation of the isolates. The M. fructicola population of São Paulo State was less sensitive to the fungicide than the population from the states of Paraná, Santa Catarina, and Rio Grande do Sul. The low sensitivity of the isolates was confirmed also by comparing to the sensitivity of the baseline isolates. Mutations in G143A, F129L, and G137R in $C y t b$ gene were not found. In addition, 58 isolates tested showed an intron after codon 143 in $C y t b$ gene. Our results indicate that other mechanisms of selection for low sensitivity to QoI fungicides should be investigated.
\end{abstract}

Brown rot is one of the most important fungal diseases of Prunus species worldwide (Mari et al. 2012; Willetts et al. 1977). Disease is caused by several species of fungi belonging to the genus Monilinia, of which M. fructicola is the most aggressive and prevalent in stone fruit in Brazil (May De Mio et al. 2008). The production of stone fruit is concentrated in southern Brazil, in the states of São Paulo (SP), Paraná (PR), Santa Catarina (SC), and Rio Grande do Sul (RS). Application of fungicides is the main strategy to control brown rot epidemics in all stone fruit producing regions in Brazil. Different fungicide groups, including methyl benzimidazole carbamates (MBCs), demethylation inhibitors (DMIs), dicarboximide, and quinone-outside inhibitors (QoIs), are recommended during flowering and preharvest to control the disease (May De Mio et al. 2011).

The QoI fungicides used in Brazil, such as azoxystrobin and pyraclostrobin, have been used mainly for peach rust (Tranzschelia discolor) control. QoI fungicides are not registered specifically to brown rot control, but its effect reducing sensitivity of Monilinia to azoxystrobin has been already observed (May De Mio et al. 2011). The producers of São Paulo State have been using an average of six azoxystrobin applications per season. Elsewhere in Brazil, a maximum of two applications per season are commonly used.

The QoI fungicides interfere with mitochondrial respiration by changing the energy patterns in the fungal cell. The fungicides block electron transfer between cytochrome $b$ and cytochrome $c l$ act on the ubiquinol oxidation site and hamper ATP production (Bartlett et al. 2002; Gisi et al. 2002). The high frequency of use of these fungicides increases selection pressure for resistant isolates (Chen et al. 2014). QoI fungicides, in general, have a recommended maximum of two to three sprays per season in several crops to avoid selection of

Corresponding author: L. L. May De Mio; E-mail: maydemio@ufpr.br

Accepted for publication 17 November 2016.

() 2017 The American Phytopathological Society resistance isolates (Beresford et al. 1999). In recent years, decreased sensitivity of individuals in $M$. fructicola populations to QoI has been observed in the U.S. and China (Amiri et al. 2010; Chen et al. 2014; Luo and Schnabel 2008). Shifts in azoxystrobin sensitivity of $M$. fructicola populations (20 isolates) from Brazil indicated the risk of resistance (May De Mio et al. 2011). Some of the isolates with reduced sensitivity from these populations were shown to compete equally well with sensitive isolates. Typically, a resistant isolate may occur at an initial frequency in the order of 1 in 1,000 million spores or other structures of the pathogen. However, after the selection pressure by the fungicide, the number of resistant isolates can increase by reaching the ratio of 1 resistant in 100 sensitive isolates (Brent and Hollomon 1998). Thus, a large number of isolates from different regions should be evaluated to detect resistant isolates in the pathogen population. It is important to investigate the QoI sensitivity in a larger number of isolates (more than 100) representative of the $M$. fructicola populations in Brazilian stone fruits.

The reduced sensitivity to QoIs may be related to the emergence of individuals with mutations in the cytochrome $b$ gene $(C y t b)$. Resistance to QoI fungicides has been attributed to three amino acid substitutions in the $C y t b$. Changes from glycine to alanine at position $143(\mathrm{G} 143 \mathrm{~A})$, from phenylalanine to leucine at position 129 (F129L), and from glycine to arginine at position 137 (G137R) have been associated to QoI resistance (Gisi et al. 2002; Klosowski et al. 2015; Semar et al. 2007). The G143A, F129 L, and G137R mutations have been reported in different countries and crops such as Cercospora beticola in sugar beet in the U.S. (Bolton et al. 2013), Phakopsora pachyrhizi in soybean in Brazil (Klosowski et al. 2015), and Pyrenospora teres in barley in France (Semar et al. 2007). G143A is considered the most important in conferring high levels of resistance, whereas F129 L and G137R mutations are less frequent and important as they confer resistance at low levels (Semar et al. 2007; Sierotzki et al. 2007).

The presence of an intron immediately following the G143A site has been shown to prevent the formation of the G143A mutation in some pathogens due to its inhibition of intronic splicing (Hily et al. 
2011; Luo et al. 2010; Miessner and Stammler 2010). Thus, the presence of the intron could determine the chance of occurrence of resistant isolates (Luo et al. 2010). The intron has been reported in M. fructicola isolates from the U.S. (Hily et al. 2011) and China (Luo et al. 2010). In both locations, none of the mutations (G143A, F129 L, and G137R) was found. All M. fructicola isolates reported in China and the U.S. so far have the intron after codon 143, confirming an intraspecific homogeneity (Hily et al. 2011; Luo et al. 2010; Miessner and Stammler 2010). In addition to the causal agent of brown rot, the intron has been reported in basidiomycetes (Grasso et al. 2006), Botrytis cinerea (Banno et al. 2009), and Phyllosticta spp. (Hincapie et al. 2014; Stammler et al. 2013).

Brazilian isolates of $M$. fructicola with reduced sensitivity to QoI fungicides were not examined for mutations in the $C y t b$ gene and presence of an intron immediately following the G143A site. This study aimed to: i) evaluate the in vitro sensitivity of $M$. fructicola isolates from different growing seasons and regions of Brazil to azoxystrobin, ii) evaluate disease control ex vivo for isolates with different levels of azoxystrobin sensitivity, iii) verify the presence of an intron linked to codon 143 in the $C y t b$ region of $M$. fructicola isolates, and iv) analyze for the G143A, F129 L, and G137R mutations in the $C y t b$ gene in a subpopulation of the pathogen with different levels of azoxystrobin sensitivity.

\section{Materials and Methods}

M. fructicola isolates. To assess the in vitro sensitivity of M. fructicola to azoxystrobin, 143 isolates were collected from spring 2002 to autumn 2011 (UFPR-LEMID Collection) from flowers, cankers on branches, symptomatic mature fruit, and mummified fruit in peach, nectarine, and plum orchards. The isolates were collected in four states of Brazil: 63 from SP, 30 from PR, 7 from SC, and 43 from RS. Single-spore cultures of each isolate were obtained and stored in potato dextrose agar (PDA) plug with fungal growth in sterile water at $4{ }^{\circ} \mathrm{C}$ and/or in $10 \%$ glycerol until use (Castellani 1967). All isolates were previously identified as $M$. fructicola using primers and protocols developed by Hily et al. (2011).

In vitro sensitivity of $M$. fructicola isolates to azoxystrobin. The sensitivity to azoxystrobin (Priori SC; Syngenta Crop Protection, Greensboro, NC) of the 143 isolates of M. fructicola was evaluated on water agar (WA), WA amended with salicylhydroxamic acid (SHAM; Sigma-Aldrich, St. Louis, MO), and WA amended with SHAM and azoxystrobin. The fungicide was dissolved in sterile water, adjusted to $10 \mu \mathrm{g}$ a.i $/ \mathrm{ml}$, and incorporated into the $2 \%$ WA to produce concentrations of $0,0.3$, or $1.0 \mu \mathrm{g} / \mathrm{ml}$. SHAM was dissolved in $100 \%$ methanol, to obtain $100 \mathrm{mg} / \mathrm{ml}$, and incorporated in WA. The methanol concentration in the WA media was $1 \mathrm{ml} / \mathrm{liter}$. Azoxystrobin and SHAM were added to the autoclaved WA media cooled to $45^{\circ} \mathrm{C}$. Conidia were obtained from 6-day-old colonies grown on PDA at $22^{\circ} \mathrm{C}$ and used for the production of spore suspensions. A $40 \mu \mathrm{l}$ aliquot of the conidial suspension $\left(4 \times 10^{5} \mathrm{conidia} / \mathrm{ml}\right)$ of each isolate was spread on the media of the different treatments. The plates containing the dispersed conidia on media were stored at $22^{\circ} \mathrm{C}$ for 9 to $12 \mathrm{~h}$. The plates were divided into four equal quadrants and conidial germination was estimated in each quadrant. One hundred conidia per quadrant were evaluated. Conidia were considered germinated if they produced germ tubes at least twice their width. The mean of the four quadrants of a Petri dish was used to represent a replicate, and each treatment was consisted of three replicates. The germ tube length was measured with the UTHSCSA Image Tool software (University of Texas, San Antonio). The incidence of germinated conidia was recorded to determine the percentage of conidial germination inhibition $(G i)$ for the isolate. This assay was carried out twice.

Determination of the $\mathrm{EC}_{50}$ of $M$. fructicola isolates to azoxystrobin. Twenty-four isolates with different levels of sensitivity to azoxystrobin were selected for this test. The fungicide was dissolved in sterile water and adjusted to $100 \mu \mathrm{g} / \mathrm{ml}$. SHAM was dissolved in $100 \%$ methanol to yield a concentration of $100 \mu \mathrm{g} / \mathrm{ml}$. The sensitivity of each isolate to azoxystrobin was determined using spore germination on $2 \%$ WA plus $0,0.05,0.1,0.2,0.4,0.8,1.6,3.2$, or $7.4 \mu \mathrm{g}$ of azoxystrobin/ml. Azoxystrobin and SHAM at $100 \mathrm{mg} / \mathrm{ml}$ were added to autoclaved the WA media cooled to $45^{\circ} \mathrm{C}$. The methanol concentration in WA was $1 \mathrm{ml} /$ liter. The conidial suspensions were prepared from 6-day-old colonies grown on PDA at $22^{\circ} \mathrm{C}$ under a $12-\mathrm{h}$ photoperiod. The conidia were adjusted in sterile water to $10^{4}$ conidia $/ \mathrm{ml}$. A $60 \mu \mathrm{l}$ aliquot of the suspension was spread on WA amended with fungicide and SHAM or WA amended with SHAM (control). They were incubated at $22^{\circ} \mathrm{C}$ in the dark for 12 $\mathrm{h}$. Evaluations were conducted as described in the previous section. Experiments were repeated using the same protocol.

Table 2. Average of germination (\%) and germ tube length $(\mu \mathrm{m})$ of 143 Monilinia fructicola isolates in water agar (WA) (control), WA amended with salicylhydroxamic acid (SHAM), and WA amended with SHAM and azoxystrobin (A) at 0.3 and $1 \mu \mathrm{g}$ a.i./ml

\begin{tabular}{lcc}
\hline Treatment & ${\text { Germination }(\%)^{\mathbf{z}}}$ & Germ tube length $(\boldsymbol{\mu m})^{\mathbf{z}}$ \\
\hline Control & $91.9 \mathrm{a}$ & $902 \mathrm{a}$ \\
SHAM & $76.3 \mathrm{~b}$ & $616 \mathrm{~b}$ \\
SHAM+A $(0.3 \mu \mathrm{g} / \mathrm{ml})$ & $18.3 \mathrm{c}$ & $235 \mathrm{c}$ \\
SHAM+A $(1.0 \mu \mathrm{g} / \mathrm{ml})$ & $2.6 \mathrm{~d}$ & $59 \mathrm{~d}$ \\
\hline
\end{tabular}

${ }^{\mathrm{z}}$ Means followed by the same letter in the same column are not significantly different based on Tukey's studentized range (honest significant difference) test $(P \leq 0.05)$.

Table 3. In vitro sensitivity of Monilinia fructicola isolates to azoxystrobin, measured by percentage inhibition of conidial germination $(\mathrm{Gi})$

\begin{tabular}{|c|c|c|c|c|c|}
\hline \multirow[b]{3}{*}{ State $^{\mathrm{x}}$} & \multirow[b]{3}{*}{ No. of isolates } & \multicolumn{4}{|c|}{$G i(\%)$} \\
\hline & & \multicolumn{2}{|c|}{$0.3 \mu \mathrm{g} / \mathrm{ml}$} & \multicolumn{2}{|c|}{$1.0 \mu \mathrm{g} / \mathrm{ml}$} \\
\hline & & $\operatorname{Mean}^{y}$ & $\mathrm{CI}^{\mathrm{Z}}$ & Mean $^{y}$ & $\mathrm{CI}^{\mathrm{z}}$ \\
\hline$\overline{\mathrm{SP}}$ & 63 & $63.11 \mathrm{~b}$ & $55.7-70.4$ & $93.47 \mathrm{~b}$ & $\overline{90.4-96.4}$ \\
\hline $\mathrm{PR}+\mathrm{SC}$ & 37 & $85.27 \mathrm{a}$ & $79.1-91.3$ & $99.70 \mathrm{a}$ & $99.1-100$ \\
\hline RS & 43 & $87.97 \mathrm{a}$ & $83.5-92.4$ & $99.69 \mathrm{a}$ & $99.2-100$ \\
\hline
\end{tabular}

x SP: Sao Paulo, PR: Paraná, SC: Santa Catarina, RS: Rio Grande do Sul.

y Means followed by the same letter in the same column are not significantly different based on Tukey's studentized range (honest significant difference) test $(P \leq 0.05)$

${ }^{\text {z }}$ Confidence interval: $C I=X-t_{a / 2} \frac{s}{\sqrt{n}} ; X+t_{a / 2} \frac{s}{\sqrt{n}}$

Table 1. Sequence, annealing temperature, extension times, and amplified region of each primer used for molecular characterization of Monilinia fructicola isolates

\begin{tabular}{|c|c|c|c|c|c|}
\hline Primer & Sequence $5^{\prime}-3^{\prime}$ & $\begin{array}{c}\text { Annealing } \\
\text { temperature }\end{array}$ & Extension time & Amplified region & Reference \\
\hline cola0-fwd & AGAGCACCTAGAACATTAGTT & $52^{\circ} \mathrm{C}$ & 1.5 & \multirow[t]{2}{*}{ Codon 129} & \multirow[t]{2}{*}{ This study } \\
\hline cola1-rev & AACCAAAGCTTGAACCCGCT & $52^{\circ} \mathrm{C}$ & 1.5 & & \\
\hline cola2-fwd & CGCGACAGGCTGGGTCACTGA & $55^{\circ} \mathrm{C}$ & 2.5 & $\begin{array}{l}\text { Codon } 137,143 \\
\text { and intron }\end{array}$ & This study \\
\hline colaexon3-fwd & TTTACCTTACGGTCAAATGAGCCT & $55^{\circ} \mathrm{C}$ & 2.5 & \multirow{4}{*}{$\begin{array}{l}\text { Codon 137, 143, } \\
\text { and intron }\end{array}$} & \multirow[t]{4}{*}{ Hily et al. 2011} \\
\hline colaexon4-rev & AACTCAACAATATCACCTCCAАTTCAT & $55^{\circ} \mathrm{C}$ & 2.5 & & \\
\hline laxaexon3-fwd & TTACCTTACGGTCAAATGTCGCTA & $55^{\circ} \mathrm{C}$ & 2.5 & & \\
\hline laxaexon4-rev & CAACAATATCTTGTCCAATTCATGGT & $55^{\circ} \mathrm{C}$ & 2.5 & & \\
\hline
\end{tabular}


Brown rot control with azoxystrobin. The same $24 \mathrm{M}$. fructicola isolates used in the $\mathrm{EC}_{50}$ assay with different levels of sensitivity to azoxystrobin were selected to evaluate the efficacy of fungicide control. The trial was conducted on fruit of two peach cultivars (Chimarrita and PS10711) that are highly susceptible to the pathogen. The fruits were surface-disinfested by immersion in $0.5 \%$ sodium hypochlorite solution ( $1 \mathrm{~min}$ ), followed by immersion in $70 \%$ ethanol ( $1 \mathrm{~min}$ ), and with three subsequent washes in sterile distilled water. The fruit were kept in a cool environment $\left(23\right.$ to $\left.25^{\circ} \mathrm{C}\right)$ to dry the excess water on the surface. This study used the method of Amiri et al. (2010) with some modifications. The fruit were immersed in sterile water (control) or fungicide solution using the recommended rate for use in the field $(0.4 \mathrm{ml} / \mathrm{liter})$ and stored at room temperature $\left(23\right.$ to $\left.25^{\circ} \mathrm{C}\right)$ for $12 \mathrm{~h}$ before inoculation. Conidial suspensions were prepared from spores produced on the surface of preinoculated fruit. An aliquot of $30 \mu \mathrm{l}$ of a suspension containing $5 \times 10^{5}$ conidia/ml of each isolate was deposited on the surface of the fruit with a $9.5 \mathrm{~mm}$ deep wound. After inoculation, fruit were kept at $22^{\circ} \mathrm{C}$ for 5 days. Lesion diameters were measured daily in two perpendicular directions and the area under the lesion growth (AULG) calculated. For comparison among isolates, the difference of each AULG with and without fungicide for each isolate $\left(\mathrm{AULG}_{\mathrm{IS}}=\right.$ $\mathrm{AULG}_{\mathrm{IS} \text {-treat }}-\mathrm{AULG}_{\mathrm{IS} \text {-cont }}$ ) was calculated. Furthermore, the time between inoculation and appearance of sporulation on the surface of the fruit (latent period) was measured. Three single-peach replicates were used. The experiment was conducted twice in a completely randomized design.
Evaluation of the presence of an intron immediately after codon 143 of the $\boldsymbol{C y t} \boldsymbol{b}$ gene in $\boldsymbol{M}$. fructicola isolates. To verify the presence of the intron after the codon 143 of the $C y t b$ gene, 58 isolates with different levels of sensitivity to the fungicide were selected. This analysis was conducted based on the methodology of Hily et al. (2011) with some modifications. Genomic DNA was extracted from these isolates using the DNA extraction kit Ultraclean Microbial (Mo Bio Laboratories, Carlsbad, CA), following the protocol established by the manufacturer. The DNA was quantified in a spectrophotometer NanoDrop 2000 (Thermo Fisher Scientific Inc., Waltham, MA) and the concentration was adjusted to $200 \mathrm{ng}$. The colaexon3-fwd and colaexon4-rev primers were used to amplify the codon 143 region of the $C y t b$ gene of the M. fructicola isolates (Table 1). PCR was conducted based on the method of Hily et al. (2011) with some modifications. A total volume of $12.5 \mu \mathrm{l}$ contained $2 \mu \mathrm{l}$ of the sample DNA, $10 \mathrm{uM}$ of each primer (colaexon3-fwd and colaexon4-rev), $2.5 \mu \mathrm{l}$ of the $10 \times$ PCR buffer solution, $1.5 \mathrm{mM}$ of $\mathrm{MgCl}_{2}, 0.2 \mathrm{mM}$ of dNTPs, and 0.4 units of Taq DNA polymerase. For the reaction, the thermocycler was programmed for one cycle of $30 \mathrm{~s}$ at $94^{\circ} \mathrm{C}$, $45 \mathrm{~s}$ at $62^{\circ} \mathrm{C}$, and $90 \mathrm{~s} 72^{\circ} \mathrm{C}$, followed by a cycle of $30 \mathrm{~s}$ at $94^{\circ} \mathrm{C}$, $45 \mathrm{~s}$ at $60^{\circ} \mathrm{C}$, and $90 \mathrm{~s} 72^{\circ} \mathrm{C}$, ending with 35 cycles of $30 \mathrm{~s}$ at $94^{\circ} \mathrm{C}$, $45 \mathrm{~s}$ at $58^{\circ} \mathrm{C}$, and $90 \mathrm{~s} 72^{\circ} \mathrm{C}$. The PCR products were visualized on $1.5 \%$ agarose gel in Tris-Borate-EDTA buffer (TBE) and stained with GelRed (Biotium Inc., Hayward, CA). DNA fragments were visualized by ultraviolet transillumination and photodocumented. If the isolates of $M$. fructicola showed an intron associated with the codon 143 of the $C y t b$ gene, a fragment of 1,258 bp was displayed;
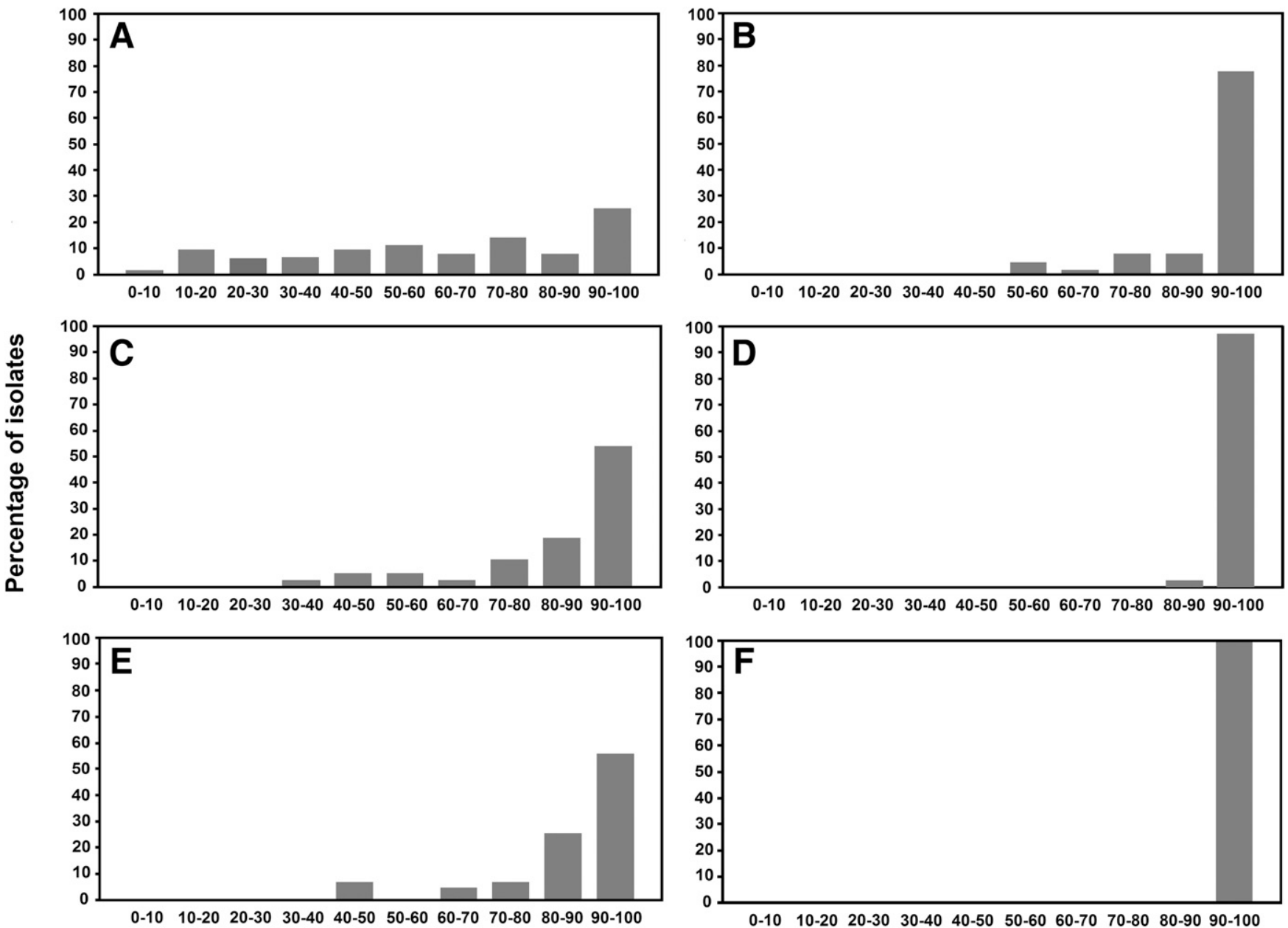

Percentage inhibition of conidial germination

Fig. 1. Frequency of the isolates in different classes of percentage inhibition of conidial germination of Monilinia fructicola. $\mathbf{A}$ and B, São Paulo population ( $n=63$ ); $\mathbf{C}$ and D, Paraná and Santa Catarina population ( $n=37)$; E and F, Rio Grande do Sul population $(n=43)$. Discriminatory dose at $0.3 \mu \mathrm{g} / \mathrm{ml}: \mathrm{A}, \mathrm{C}$, and E; $1 \mu \mathrm{g} / \mathrm{ml}: \mathrm{B}, \mathrm{D}$, and F. 
however, if the observed fragment was $92 \mathrm{bp}$, the absence of the intron $(1,166 \mathrm{bp})$ was indicated.

Cyt $b$ gene analysis to assess the potential mutations G143A, F129 $L$, and G137R and the association of the intron after codon 143. For the analyses of potential mutations in codons 143 , 137 , and 129 of the $C y t b$ gene and the occurrence of an intron immediately after the codon 143, nine isolates from the 2005-2011 UFPRLEMID Collection (Paraná and São Paulo) and 10 isolates from São Paulo State collected in the 2012-13 season were used. The DNA of the 19 selected isolates was extracted from 10-day-old cultures, using the modified CTAB protocol (Doyle and Doyle 1987) or the Wizard DNA purification kit (Promega, Madison, WI), according to manufacturer's recommendations. Nucleic acids were quantified on the NanoDrop 1000 spectrophotometer. PCR was performed in $50-\mu 1$ volumes containing $35.1 \mu \mathrm{l}$ of water, $5 \mu \mathrm{l}$ of $10 \times$ buffer, $1.5 \mu \mathrm{l}$ of $50 \mathrm{mM} \mathrm{MgCl}_{2}$, $1 \mu \mathrm{l}$ of dNTP, $2.5 \mu \mathrm{l}$ of each primer $(10 \mathrm{uM}), 0.4 \mu \mathrm{l}$ of Taq $\left(5 \mathrm{U} . \mu 1^{-1}\right)$, and $2 \mu \mathrm{l}$ of DNA or water (control); conditions were $95^{\circ} \mathrm{C}$ for $2 \mathrm{~min}$, followed by 29 cycles of $95^{\circ} \mathrm{C}$ for $30 \mathrm{~s}, 52$ or $55^{\circ} \mathrm{C}$ for $30 \mathrm{~s}, 68^{\circ} \mathrm{C}$ for 1.5 or $2.5 \mathrm{~min}$, and final extension of $5 \mathrm{~min}$ at $68^{\circ} \mathrm{C}$ (Table 1). PCR products were visualized on agarose gel at $1.5 \%$ and $5-\mu l$ aliquots of each sample were mixed with $1 \mu$ l of diluted GelRed (1:50) in the buffer.

An enzymatic cleaning, ExoSAP-IT (USB Corp., Cleveland, OH), of all PCR products was performed. Five microliters of each PCR sample were mixed with $2 \mu l$ of ExoSAP-IT and this mixture was incubated at $37^{\circ} \mathrm{C}$ for $15 \mathrm{~min}$ and then at $80^{\circ} \mathrm{C}$ for $15 \mathrm{~min}$. After this incubation period, $15 \mu \mathrm{l}$ of water was added, totaling $22 \mu \mathrm{l}$. Before sending for sequencing (Genewiz, South Plainfield, NJ), each sample was divided into $10 \mu \mathrm{l}$ for the forward primer and $10 \mu \mathrm{l}$ for the reverse primer. The reverse sequences were converted using the "Reverse Complement" program (https://www.ualberta.ca/ stothard/ javascript/rev_comp.html) and all nucleotide sequences were aligned using the "Clustal Omega" program (http://www.ebi.ac.uk/Tools/ $\mathrm{msa} / \mathrm{clustalo} /$ ). The consensus sequences were defined and compared with sequences of the cytochrome $b$ of $M$. fructicola available in GenBank, using the program BioEdit version 7.2.5.

Data analysis. Germination inhibition (Gi) was calculated by the following equation: $G i=\left(G_{t c}-G_{t}\right) / G_{t c} \times 100$, where $G_{t c}$ and $G_{t}$ are the average frequencies of germinated conidia in treatments without and with fungicide, respectively. Analysis of variance (ANOVA) was performed on the data of sensitivity of $M$. fructicola isolates to azoxystrobin and the treatment means were compared by Tukey's Student Range test (honest significant difference, $P<0.05$ ). The $\mathrm{EC}_{50}$ of $M$. fructicola isolates to azoxystrobin was calculated by linear regressions between $G i$ and the $\log _{10}$ of the fungicide concentration. The values $G i$, area under the lesion growth of each isolate (AULG $\mathrm{AS}_{\mathrm{IS}}$, latent period (LP), and $\mathrm{EC}_{50}$ estimated for each isolate were utilized in the multivariate analysis. The data were subjected to cluster analysis after standardization of the variables (the mean of the values for each variable was subtracted from each variable value and the result was divided by the standard deviation of the values for each variable) using the Minkowski distance and Ward's method as a clustering technique. Confidence interval $(C I)$ was calculated by the following equation:

$$
C I=X-t_{a / 2} \frac{s}{\sqrt{n}} ; X+t_{a / 2} \frac{s}{\sqrt{n}}
$$

where $X$ is average of the observed values, $t_{a / 2}$ is tabulated value for bilateral $t$ test with $95 \%$ confidence, $s$ is standard deviation, and $n$ is the number of observed values. All statistical analyses were conducted with the R software version 3.1.3 (R Development Core Team 2015).

\section{Results}

A significant decrease in germination and germ tube growth of conidia on WA with SHAM was observed when compared with the control without SHAM (Table 2). The average spore germination and the size of the germ tube in WA (control) was $91.87 \%$ and $902 \mu \mathrm{m}$,

Table 4. Percentage inhibition of conidial germination (Gi), area under lesion growth (AULG), latent period (LP), and concentration for $50 \%$ inhibition of conidial germination $\left(\mathrm{EC}_{50}\right)$ of Monilinia fructicola isolates

\begin{tabular}{|c|c|c|c|c|c|c|c|c|}
\hline \multirow{2}{*}{ Isolates } & & \multicolumn{2}{|c|}{$G i(\%)$} & \multicolumn{2}{|c|}{ First assay } & \multicolumn{2}{|c|}{ Second assay } & \multirow[b]{2}{*}{$\mathrm{EC}_{50}(\mu \mathrm{g} / \mathrm{ml})$} \\
\hline & & $0.3 \mu \mathrm{g} / \mathrm{ml}$ & $1 \mu \mathrm{g} / \mathrm{ml}$ & $\mathbf{A U L G}_{\mathbf{I S}} \mathbf{y}^{\mathbf{y}}$ & LP (days) & $\mathbf{A U L G}_{\mathbf{I S}}{ }^{\mathbf{y}}$ & LP (days) & \\
\hline \multirow[t]{15}{*}{ Low sensitivity } & SP06-213 & 22.05 & 82.42 & 6.86 & 2.3 & 1.29 & 2.0 & 0.23 \\
\hline & SP07-317 & 44.89 & 83.86 & 7.00 & 2.3 & 4.13 & 2.3 & 0.28 \\
\hline & SP08-343 & 24.70 & 79.36 & 7.19 & 2.5 & 2.99 & 2.0 & 0.36 \\
\hline & SP08-345 & 13.06 & 79.16 & 6.84 & 2.5 & 2.59 & 2.5 & 0.45 \\
\hline & SP09-829 & 28.52 & 84.27 & 7.06 & 2.3 & 1.00 & 2.0 & 0.17 \\
\hline & SP09-834 & 5.42 & 54.88 & 12.03 & 2.0 & 1.57 & 2.0 & 0.39 \\
\hline & SP09-839 & 31.16 & 54.51 & 6.02 & 2.0 & 0.71 & 2.0 & 0.32 \\
\hline & SP09-860 & 19.87 & 77.23 & 7.86 & 2.3 & 1.85 & 2.0 & 0.51 \\
\hline & SP09-885 & 29.65 & 50.70 & 7.07 & 2.0 & 3.74 & 2.0 & 0.63 \\
\hline & SP09-888 & 26.30 & 82.35 & 11.04 & 2.3 & 2.37 & 2.0 & 0.35 \\
\hline & SP09-940 & 23.75 & 85.75 & 14.89 & 4.8 & 2.18 & 2.0 & 0.26 \\
\hline & SP09-945 & 76.46 & 83.13 & 5.29 & 2.0 & 1.27 & 2.0 & 0.27 \\
\hline & SP09-951 & 42.72 & 70.26 & 14.08 & 4.5 & 1.33 & 2.3 & 0.33 \\
\hline & SP09-956 & 42.53 & 79.94 & 16.46 & 5.3 & 2.58 & 2.0 & 0.31 \\
\hline & $\begin{array}{l}\text { Average } \\
\text { CI }^{\mathbf{z}}\end{array}$ & $\begin{array}{l}30.08 \text { b } \\
(20.78 ; 39.36)\end{array}$ & $\begin{array}{l}75.48 \text { b } \\
68.79 ; 82.17)\end{array}$ & $\begin{array}{l}9.12 \mathrm{a} \\
(7.14 ; 11.11)\end{array}$ & $\begin{array}{l}2.76 \mathrm{~b} \\
(2.14 ; 3.38)\end{array}$ & $\begin{array}{l}2.03 \mathrm{a} \\
(1.46 ; 2.60)\end{array}$ & $\begin{array}{l}2.07 \text { b } \\
(1.96 ; 2.16)\end{array}$ & $\begin{array}{l}0.35 \text { b } \\
(0.29 ; 0.41)\end{array}$ \\
\hline \multirow{10}{*}{ High sensitivity } & SP08-340 & 100.00 & 100.00 & 16.37 & 4.3 & 2.30 & 3.0 & 0.06 \\
\hline & RS08-311 & 88.48 & 95.02 & 9.04 & 5.0 & 3.41 & 4.0 & 0.12 \\
\hline & RS08-329 & 100.00 & 100.00 & 8.80 & 3.0 & 3.19 & 4.0 & 0.13 \\
\hline & RS08-335 & 100.00 & 100.00 & 9.43 & 4.0 & 2.67 & 2.0 & 0.11 \\
\hline & RS10-979 & 47.51 & 100.00 & 13.87 & 5.0 & 2.47 & 4.0 & 0.17 \\
\hline & RS11-140 & 74.72 & 100.00 & 13.29 & 3.8 & 5.15 & 4.0 & 0.12 \\
\hline & PR02-100 & 81.66 & 100.00 & 14.13 & 5.5 & 3.59 & 3,0 & 0.05 \\
\hline & PR08-190 & 80.05 & 100.00 & 16.85 & 5.0 & 3.23 & 3.0 & 0.42 \\
\hline & PR11-13 & 67.32 & 100.00 & 9.29 & 3.5 & 1.25 & 2.0 & 0.37 \\
\hline & $\begin{array}{l}\text { Average } \\
\text { CI }^{\mathbf{z}}\end{array}$ & $\begin{array}{l}82.19 \text { a } \\
(68.67 ; 95.71)\end{array}$ & $\begin{array}{l}99.45 \text { a } \\
(85.17 ; 100)\end{array}$ & $\begin{array}{l}12.34 \text { a } \\
(9.85 ; 14.83)\end{array}$ & $\begin{array}{l}4.34 \mathrm{a} \\
(3.70 ; 4.98)\end{array}$ & $\begin{array}{l}3.03 \mathrm{a} \\
(2.21 ; 3.85)\end{array}$ & $\begin{array}{l}3.22 \mathrm{a} \\
(2.68 ; 3.83)\end{array}$ & $\begin{array}{l}0.17 \text { a } \\
(0.07 ; 0.27)\end{array}$ \\
\hline
\end{tabular}

\footnotetext{
${ }^{\mathrm{z}}$ Confidence Interval:$$
C I=X-t_{a / 2} \frac{s}{\sqrt{n}} ; X+t_{a / 2} \frac{s}{\sqrt{n}}
$$

${ }^{\mathrm{y}} \mathrm{AULG}_{\mathrm{IS}}=\mathrm{AULG}_{\mathrm{IS} \text {-treat }}-\mathrm{AULG}_{\mathrm{IS}-\text { cont }}$ 
respectively. The conidia exposed to SHAM had a mean germination and germ tube length of $76.3 \%$ and $616 \mu \mathrm{m}$, respectively (Table 2).

The mean percentage inhibition of conidial germination $(\mathrm{Gi})$ at $0.3 \mu \mathrm{g} / \mathrm{ml}$ of azoxystrobin for the SP population was $63.1 \%$ with a confidence interval of 55.7 to $70.4 \%$ (Table 3 ). At this concentration, isolates of this population were distributed in all $G i$ classes (Fig. 1A). Populations from southern Brazil showed similar behavior, with germination inhibition above $85 \%$ (Table 3, Fig. $1 \mathrm{C}$ and E). At $1 \mu \mathrm{g} / \mathrm{ml}$ of azoxystrobin, the average $\mathrm{Gi}$ for the SP population was $93.5 \%$ (Table 3). Two groups of sensitivity were observed in this population: one group with $\mathrm{Gi}$ ranging from 50 to $90 \%$ and another from 90 to $100 \%$ (Fig. 1B). The average $G i$ of the PR/SC and RS populations was greater than $99 \%$ (Table 3, Fig. 1D and F). There was no significant difference between $G i$ values of the PR/SC and RS populations $(P>0.05)$. However, the $G i$ values of these populations were significantly different $(P<0.05)$ from the values found in the SP population at 0.3 and $1 \mu \mathrm{g} / \mathrm{ml}$ of azoxystrobin (Table 3 ).

$M$. fructicola isolates from stone fruits were initially classified into two groups according to the $G i$ at 0.3 and $1 \mu \mathrm{g} / \mathrm{ml}$ : isolates with high or low sensitivity to azoxystrobin (Table 4 ). The average time for sporulation of isolates with low sensitivity was 2.8 and 2.1 days in the first and second assay, respectively. The group of isolates with higher sensitivity showed average sporulation times of 4.3 and 3.2 days in the first and second assay, respectively (Table 4). The average $\mathrm{EC}_{50}$ of the group of isolates with lower sensitivity to fungicide was $0.35 \mu \mathrm{g} / \mathrm{ml}$, significantly higher than the $\mathrm{EC}_{50}$ value of the group with higher sensitivity of $0.17 \mu \mathrm{l} / \mathrm{ml}$ (Table 4 ). There was no difference in the AULG of the treatment compared with the AULG of the control (without fungicide) and there was no significant difference between the groups of isolates with higher and lower sensitivity to the fungicide (Table 4).

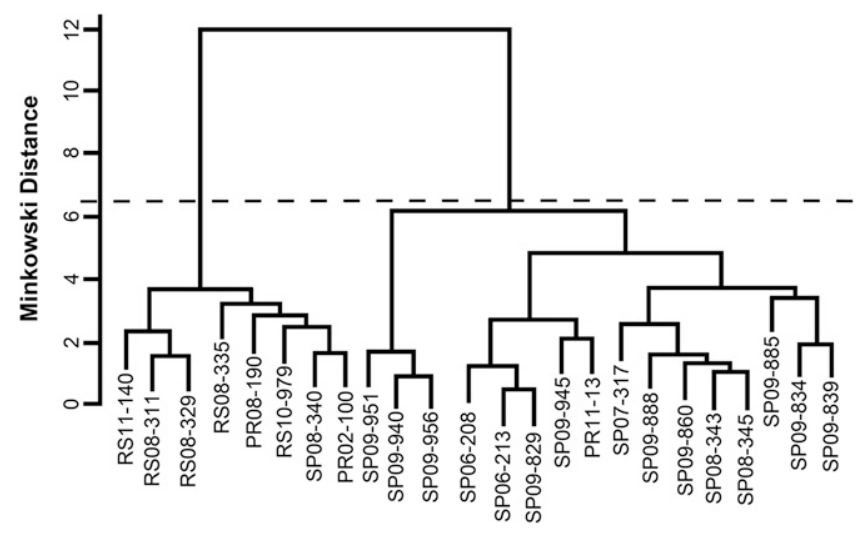

Fig. 2. Dendrogram of Monilinia fructicola isolates in groups according to combined analysis of latent period, effective concentration for $50 \%$ inhibition of conidial germination, percentage of conidial germination inhibition, and area under the lesion growth of each isolate. The dotted line represents the Minkowki distance value used to separate the two clades of isolates.
The dendrogram separated the isolates into two groups according to combined analysis of latent period and $\mathrm{EC}_{50}$ of conidial germination (Fig. 2). A group of eight isolates had greater sensitivity to the fungicide. This group was composed of isolates from all regions, mostly from PR and RS. Another group consisted of 16 isolates with low sensitivity to the fungicide, all of which, except for the isolate PR11-13 from PR, came from SP (Fig. 2).

All M. fructicola isolates (subpopulation of 58 isolates) yielded fragments of $1,258 \mathrm{bp}$, which corresponded to the presence of introns associated with the G143 codon in the Cyt b gene (Fig. 3). The cola 2-fwd primer was designed and used with colaexon4rev to amplify the codons 137 and 143 and the $1,166 \mathrm{bp}$ intron (fragments from 1,305 to 1,316 bp) (Fig. 4A). Besides this primer, a pair of primers, cola0-fwd and cola1-rev, were designed based on sequences deposited in the GenBank to amplify codon 129 (608-bp fragment). All isolates of $M$. fructicola had identical sequences (Fig. 4). No isolate showed any mutation in codons 129, 137, and 143, and a group I intron was located after codon 143 (Figs. 5 and 6). The intron-exon organization was the same as that of $C y t$ $b$ sequences of other $M$. fructicola isolates in GenBank, showing $100 \%$ identity with accession numbers GU933643 (Miessner and Stammler 2010), GQ304941 (Luo et al. 2010), and GU952815 (Villani and Cox 2009). The sequences for Brazilian isolates SP05160 and 4A are available in GenBank under accession numbers KM610206 and KM610207, respectively.

\section{Discussion}

In this study, differences in the sensitivity of $M$. fructicola to azoxystrobin were found between sampled regions in Brazil. The population from SP has a lower sensitivity to the fungicide than the populations from PR, SC, and RS. The analysis of the $C y t b$ region showed that isolates from all these regions in Brazil have an intron associated with codon 143, indicating that mutations in this codon are unlikely to select for less sensitive individuals (Fig. 3). Other possible changes in $C y t$ b gene, such as F129 L and G137R, were not found in a subpopulation of the pathogen evaluated in this study. Our results reinforce a high intraspecific homogeneity of $M$. fructicola populations as previously observed in populations of U.S. (Hily et al. 2011) and China (Luo et al. 2010).

Low sensitivity of $M$. fructicola isolates to azoxystrobin in Brazil has been observed in areas with high spray frequency (3 to 6/season), whereas high sensitivity was detected in areas with low frequency of application (less than 2) (May De Mio et al. 2011). Sensitivity of M. fructicola has also been reported in other countries such as the United States (Luo and Schnabel 2008) and China (Chen et al. 2014).

Baseline sensitivity to azoxystrobin $\left(\mathrm{EC}_{50}\right)$ in M. fructicola populations was $0.15 \mu \mathrm{g} / \mathrm{ml}$ in the U.S. (Amiri et al. 2010) and 0.05 to $0.13 \mu \mathrm{g} / \mathrm{ml}$ in Brazil (May De Mio et al. 2011). In SP, the average $\mathrm{EC}_{50}$ of $M$. fructicola isolates was $0.35 \mu \mathrm{g} / \mathrm{ml}$, clearly indicating a decrease in the sensitivity of this population to the fungicide. M. fructicola isolates collected in the states of PR,

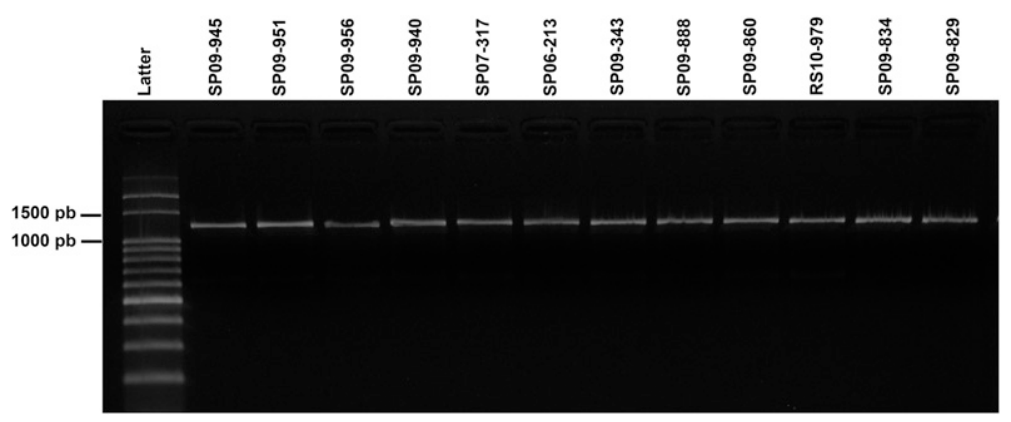

Fig. 3. Analysis of the cytochrome $b$ gene for the presence of an intron associated with the G143 codon in Monilinia fructicola isolates. PCR fragments using primers (colaexon3-fwd and colaexon4-rev) that anneal on both sides of the G143 codon are presented for representative isolates of $M$. fructicola with different levels of sensitivity to azoxystrobin. 
$\mathrm{SC}$, and RS showed $\mathrm{EC}_{50}$ values close to the baseline values (Table 4), indicating that the pathogen population is more sensitive to the fungicide compared with the population in São Paulo. In the United States, Amiri et al. (2010) investigated the sensitivity of $157 \mathrm{M}$. fructicola isolates collected between 2006 and 2008 and found mean $\mathrm{EC}_{50}$ values ranging from 0.05 to $0.6 \mu \mathrm{g} / \mathrm{ml}$ in South Carolina and Georgia, with conidial germination assays. In mycelial growth assays, the same authors determined an $\mathrm{EC}_{50}$ of 0.9 and $1.2 \mu \mathrm{g} / \mathrm{ml}$. In China, $\mathrm{EC}_{50}$ values ranged from 0.02 to $1.94 \mu \mathrm{g} / \mathrm{ml}$ for mycelial growth (Chen et al. 2014).
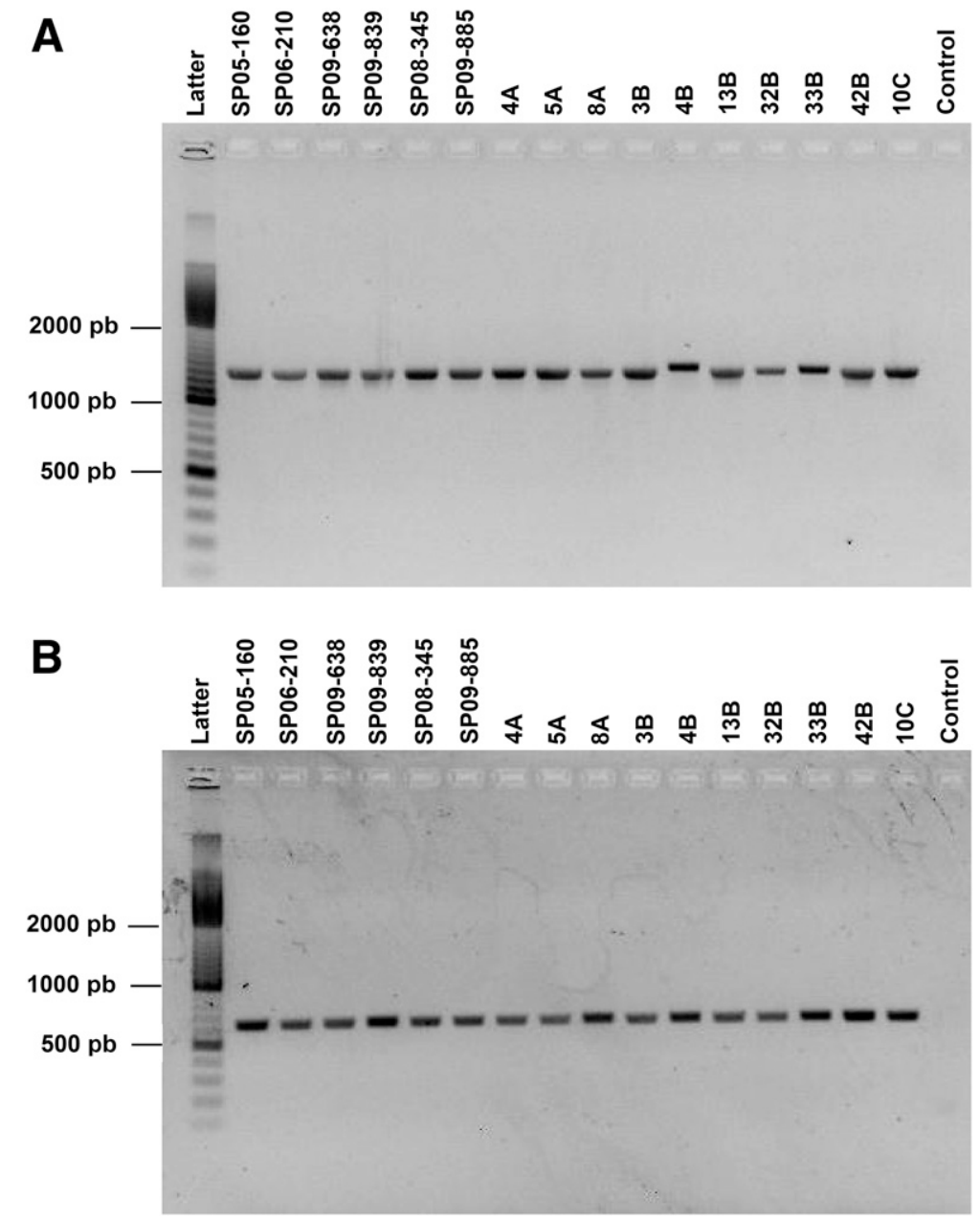

Fig. 4. A, Amplified DNA fragments with the cola2-fwd and colaexon4-rev primers for cytochrome $b$ gene (Cyt $b$ ) region including codons 137, 143, and intron (1,166 bp) of Monilinia fructicola isolates with different levels of sensitivity to azoxystrobin and B, DNA fragments amplified with cola0-fwd and cola1-rev primers for Cyt $b$ region including codon 129 of $M$. fructicola isolates with different levels of sensitivity to azoxystrobin. Water was used as the control.

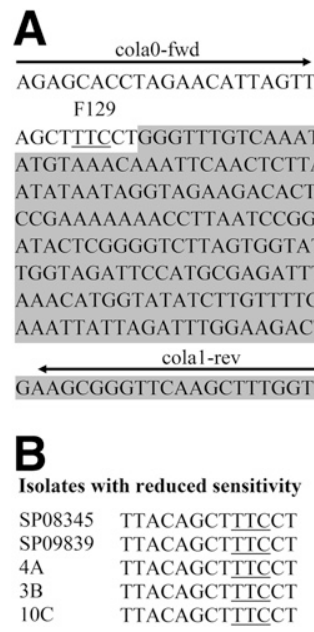

Fig. 5. A, Sequence of codon 129 of the cytochrome $b$ gene (Cyt b) from Monilinia fructicola obtained by the primer pairs cola0-fwd and cola1-rev. Text highlighted in gray indicates part of the intron (566 bp), arrows indicate the position of the sequence of the primer $\left(5^{\prime}-3^{\prime}\right)$, bold and underlined text indicates the codon associated with partial resistance (F129) to Qols. B, Cyt b partial nucleotide sequences from representative M. fructicola isolates sensitive or with reduced sensitivity to azoxystrobin. Codon 129 is underlined and in bold 


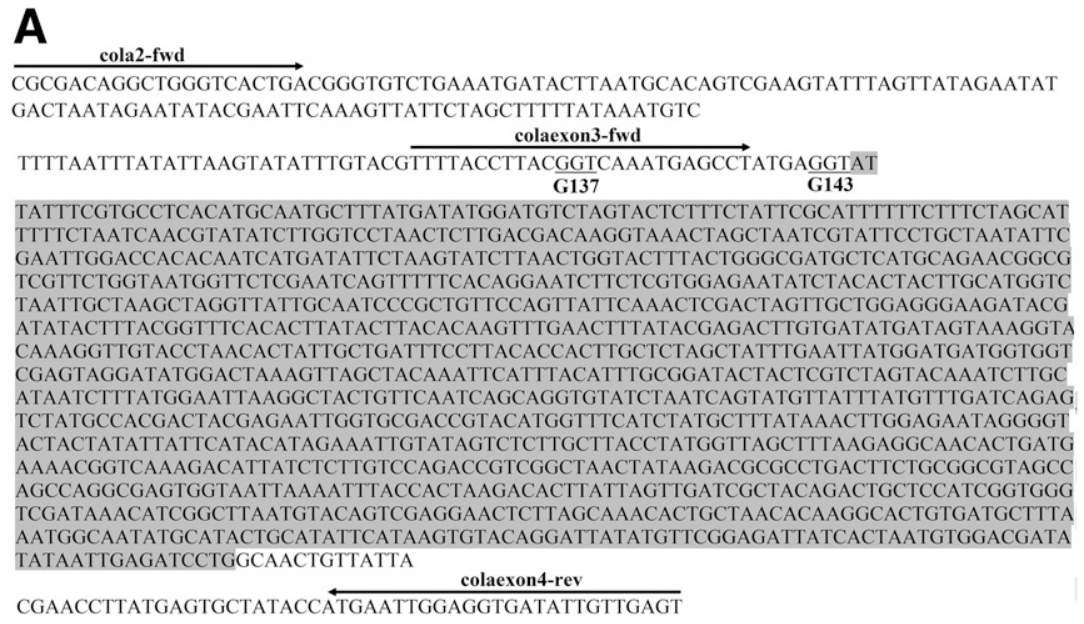

B

\begin{tabular}{|c|c|}
\hline teduced & \\
\hline SP08345 & GGTCAAATGAGCCTATGAGGTATTATT \\
\hline SP09839 & GAGCCTATGAGGTATTATT \\
\hline $4 \mathrm{~A}$ & GGTCAAATGAGCCTATGA $\overline{\text { GGTATTATT }}$ \\
\hline 3B & TGAGCCTATGAGGTATTATT \\
\hline & \\
\hline
\end{tabular}

Sensitive isolate

SP05160 GGTCAAATGAGCCTATGAGGTATTATT SP06210 GGTCAAATGAGCCTATGAGGTATTATT PR09638 GGTCAAATGAGCCTATGAGGTATTATT I0C GGTCAAATGAGCCTATGAGGTATTATT

SP09885 GGTCAAAT

Fig. 6. A, Sequence of regions including codons 137 (G137), 143 (G143), and the intron of the cytochrome $b$ gene (Cyt $b$ ) from Monilinia fructicola isolates with different levels of azoxystrobin sensitivity. Text highlighted in gray indicates the intron (1,166 bp), arrows indicate the position of the sequence of the primer $\left(5^{\prime}-3^{\prime}\right)$, bold and underlined text indicates the codon associated with partial (G137) or total (G143) resistance to Qols. B, Partial sequences of the Cyt $b$ nucleotide from representative reduced sensitivity and sensitive isolates. Codons 137 and 143 are underlined and in bold and part of the intron is highlighted in gray.

The reduction in fungal sensitivity to azoxystrobin can be qualitative or quantitative. The qualitative type confers full resistance and is commonly associated with mutations in the Cyt $b$ gene, and the quantitative type changes the sensitivity of the isolates to the fungicide and may not confer practical resistance to QoIs (Köller et al. 2004). Qualitative resistance may be preceded by a quantitative one, as observed in Venturia inaequalis isolates resistant to trifloxystrobin and kresoxim methyl (Köller et al. 2004). The mutation at codon 143 (G143A) of $C y t b$ is the resistance mechanism most associated with the complete absence of disease control in the field by QoI fungicides of various pathogenic fungi, such as Magnaporthe oryzae (Castroagudín et al. 2015; Kim et al. 2003). All M. fructicola isolates analyzed in this study showed no qualitative resistance, and the same intron-exon organization that has been described in previous studies with M. fructicola isolates in the U.S., China, Australia, and New Zealand (Hily et al. 2011; Luo et al. 2010; Miessner and Stammler 2010).

The occurrence of practical resistance has been studied in the laboratory, for example, on detached fruit (ex vivo). According to Chen et al. (2014), fruit inoculated with less sensitive $M$. fructicola isolates, after azoxystrobin treatment, had more brown rot symptoms (practical resistance). In the same experiment, the authors confirm that fruit inoculated with sensitive isolates had no symptoms of the disease. Likewise, Amiri et al. (2010) observed the same ratio comparing isolates of different sensitivity levels. Our results showed differences on the latent period of isolates with high and low sensitivity. The isolates with high sensitivity to fungicide had an average sporulation delay of about 1.4 days. Burnett et al. (2010) evaluated the antisporulant capacity on treated or nontreated fruit with azoxystrobin and noted a $15.9 \%$ reduction in sporulation on fruit treated with the fungicide, which supports the results of this study.

In conclusion, there was a clear change in sensitivity levels of M. fructicola isolates to azoxystrobin in Brazil. The common mutations related to resistance to QoIs (G143A, F129 L, and G137R) were not found, suggesting that further studies should be directed to another reduced sensitivity mechanism. Moreover, monitoring of the isolates in the orchards should be continued.

\section{Acknowledgments}

We thank Karla Kudlawiek for technical assistance, Dr. Cristiano Nunes Nesi for statistical support, and stone fruit producers of the Rio Grande do Sul, Santa Catarina, Paraná, and São Paulo states. This work was supported by the National Counsel of Technological and Scientific Development (CNPq) [grant number 79041/2010-5 Universal/CNPq] and Coordination for the Improvement of Higher Education Personnel (CAPES) [Grant n.2829/2010]. We also thank CAPES for the post-doctoral fellowships of the Wagner V. Pereira and Rafael G. F. Morales and FAPESP (2014/09472-5) for the master grant to Isabela V. Primiano. The opinions, assumptions, conclusions, and recommendations expressed in this paper are those of the authors and do not necessarily reflect the views of FAPESP.

\section{Literature Cited}

Amiri, A., Brannen, P., and Schnabel, G. 2010. Reduced sensitivity in Monilinia fructicola field isolates from South Carolina and Georgia to respiration inhibitor fungicides. Plant Dis. 94:737-743.

Banno, S., Yamashita, K., Fukumori, F., Okada, K., Uekusa, H., Takagaki, M., Kimura, M., and Fujimura, M. 2009. Characterization of QoI resistance in Botrytis cinerea and identification of two types of mitochondrial cytochrome $b$ gene. Plant Pathol. 58:120-129.

Bartlett, D. W., Clough, J. M., Godwin, J. R., Hall, A. A., Hamer, M., and ParrDobrzanski, B. 2002. The strobilurin fungicides. Pest Manag. Sci. 58:649-662.

Beresford, R., Pak, H., Brown, G., Follas, G., and Hagerty, G. 1999. Strategies to avoid resistance development to stobilurin and related fungicides in New Zealand. Pages 179-181 in: Proceedings of the 52nd New Zealand Plant Protection Conference.

Bolton, M. D., Rivera, V., and Secor, G. 2013. Identification of the G143A mutation associated with QoI resistance in Cercospora beticola field isolates from Michigan, United States. Pest Manag. Sci. 69:35-39.

Brent, K. J., and Hollomon, D. W. 1998. Fungicide resistance: the assessment of risk, FRAC, Global Crop Protection Federation, Brussels. Monogr. 2:1-48.

Burnett, A. L., Lalancette, N., and McFarland, K. A. 2010. Effect of QoI fungicides on colonization and sporulation of Monilinia fructicola on peach fruit and blossom blight cankers. Plant Dis. 94:1000-1008.

Castellani, A. 1967. Maintenance and cultivation of common pathogenic fungi of man in sterile distilled water: Further researches. J. Trop. Med. Hyg. 70: 181-184.

Castroagudín, V. L., Ceresini, P. C., De Oliveira, S. C., Reges, J. T. A., Maciel, J. L. N., Bonato, A. L. V., Dorigan, A. F., and McDonald, B. A. 2015. Resistance to QoI fungicides is widespread in Brazilian populations of the wheat blast pathogen Magnaporthe oryzae. Phytopathology 105:284-294.

Chen, S. N., Shang, Y., Wang, Y., Schnabel, G., Lin, Y., Yin, L. F., and Luo, C. X. 2014. Sensitivity of Monilinia fructicola from peach farms in china to four fungicides and characterization of isolates resistant to carbendazim and azoxystrobin. Plant Dis. 98:1555-1560. 
Doyle, J. J., and Doyle, J. L. 1987. A rapid DNA isolation procedure for small quantities of fresh leaf tissue. Phytochem. Bull. 19:11-15.

Gisi, U., Sierotzki, H., Cook, A., and McCaffery, A. 2002. Mechanisms influencing the evolution of resistance to QoI inhibitor fungicides. Pest Manag. Sci. 58:859-867.

Grasso, V., Sierotzki, H., Garibaldi, A., and Gisi, U. 2006. Characterization of the cytochrome $b$ gene fragment of Puccinia species responsible for the binding site of QoI fungicides. Pestic. Biochem. Physiol. 84:72-82.

Hily, J. M., Singer, S. D., Villani, S. M., and Cox, K. D. 2011. Characterization of the cytochrome $b$ (cyt $b$ ) gene from Monilinia species causing brown rot of stone and pome fruit and its significance in the development of QoI resistance. Pest Manag. Sci. 67:385-396.

Hincapie, M., Wang, N. Y., Peres, N. A., and Dewdney, M. M. 2014. Baseline sensitivity of Guignardia citricarpa isolates from Florida to azoxystrobin and pyraclostrobin. Plant Dis. 98:780-789.

Kim, Y. S., Dixon, E. W., Vincelli, P., and Farman, M. L. 2003. Field resistance to strobilurin (QoI) fungicides in Pyricularia grisea caused by mutations in the mitochondrial cytochrome $b$ gene. Phytopathology 93:891-900.

Klosowski, A. C., May De Mio, L. L., Miessner, S., Rodrigues, R., and Stammler, G. 2015. Detection of the F129L mutation in the cytochrome $b$ gene in Phakopsora pachyrhizi. Pest Manag. Sci. 72:1211-1215.

Köller, W., Parker, D. M., Turechek, W. W., Avila-Adame, C., and Cronshaw, K. 2004. A two-phase resistance response of Venturia inaequalis populations to the QoI fungicides kresoxim-methyl and trifloxystrobin. Plant Dis. 88:537-544.

Luo, C. X., Hu, M. J., Jin, X., Yin, L. F., Bryson, P. K., and Schnabel, G. 2010. An intron in the cytochrome $b$ gene of Monilinia fructicola mitigates the risk of resistance development to QoI fungicides. Pest Manag. Sci. 66:1308-1315.

Luo, C. X., and Schnabel, G. 2008. Adaptation to fungicides in Monilinia fructicola isolates with different fungicide resistance phenotypes. Phytopathology 98 : 230-238.

Mari, M., Martini, C., Guidarelli, M., and Neri, F. 2012. Postharvest biocontrol of Monilinia laxa, Monilinia fructicola and Monilinia fructigena on stone fruit by two Aureobasidium pullulans strains. Biol. Control 60:132-140.

May De Mio, L. L., Luo, Y., and Michailides, T. J. 2011. Sensitivity of Monilinia fructicola from Brazil to tebuconazole, azoxystrobin, and thiophanate-methyl and implications for disease management. Plant Dis. 95:821-827.

May De Mio, L. L., Moreira, L. M., Monteiro, L. B., and Justiniano Júnior, P. R 2008. Infecção de Monilinia fructicola no período da floração e incidência de podridão parda em frutos de pessegueiro em dois sistemas de produção. Trop. Plant Pathol. 33:227-234.

Miessner, S., and Stammler, G. 2010. Monilinia laxa, M. fructigena and M. fructicola: Risk estimation of resistance to QoI fungicides and identification of species with cytochrome $b$ gene sequences. J. Plant Dis. Prot. 117 162-167.

Semar, M., Strobel, D., Koch, A., Klappach, K., and Stammler, G. 2007. Field efficacy of pyraclostrobin against populations of Pyrenophora teres containing the F129L mutation in the cytochrome $b$ gene. J. Plant Dis. Prot. 114:117-119.

Sierotzki, H., Frey, R., Wullschleger, J., Palermo, S., Karli, S., Godwin, J., and Gisi, U. 2007. Cytochrome $b$ gene sequence and structure of Pyrenophora teres and P. tritici-repentis and implications for QoI resistance. Pest Manag. Sci. 63:225-233.

Stammler, G., Schutte, G. C., Speakman, J., Miessner, S., and Crous, P. W. 2013 Phyllosticta species on citrus: risk estimation of resistance to QoI fungicides and identification of species with cytochrome $b$ gene sequences. Crop Prot. 48:6-12.

Villani, S. M., and Cox, K. D. 2009. Molecular characterization and fungicide sensitivity profiling of Monilinia laxa from a cherry orchard in western NY. Phytopathology 99:S135-S135.

Willetts, H., Byrde, R., Fielding, A., and Wong, A. L. 1977. The taxonomy of the brown rot fungi (Monilinia spp.) related to their extracellular cell walldegrading enzymes. J. Gen. Microbiol. 103:77-83. 